\title{
Effects of prokinetic drugs on the abdominal wall wound healing of rats submitted to segmental colectomy and colonic anastomosis ${ }^{1}$
}

\author{
Efeitos de drogas procinéticas na cicatrização da parede abdominal de ratos submetidos à \\ colectomia segmentar e anastomose no cólon esquerdo
}

\author{
Pedro Henrique Alves de Morais, Naiara Galvão da Silva ${ }^{\mathrm{II}}$, Marcos Vinícius Melo de Oliveira ${ }^{\mathrm{II}}$, Alexandre Malta Brandão ${ }^{\mathrm{II}}$, \\ Silvana Marques e Silva ${ }^{\text {III }}$, Fabiana Pirani Carneiro' ${ }^{\text {IV }}$, João Batista de Sousav \\ IGraduate student, School of Medicine, UnB, Brasilia-DF, Brazil. Involved with technical procedures, acquisition and interpretation of data, statistical \\ analysis and manuscript writing.

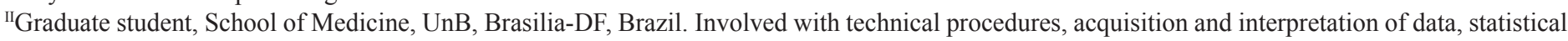 \\ analysis and critical revision.

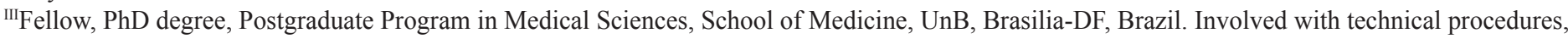 \\ acquisition and interpretation of data, statistical analysis and critical revision. \\ ${ }^{\text {IV }} \mathrm{PhD}$, Associate Professor of Pathology, School of Medicine, UnB, Brasilia-DF, Brazil. Macroscopic and histopathological examinations, interpretation \\ of data and critical revision. \\ ${ }^{\mathrm{v}} \mathrm{PhD}$, Associate Professor, Surgical Clinics, School of Medicine, UnB, Brasilia-DF, Brazil. Responsible for intellectual and scientific content of the \\ study, designed the protocol, interpretation of data, manuscript writing, critical revision and final approval.
}

\section{ABSTRACT}

PURPOSE: To assess the effect of prokinetic agents on abdominal wall wound healing in rats submitted to segmental colectomy and colonic anastomosis.

METHODS: Sixty rats were randomly allocated into three groups according to the agents they would receive in the postoperative period: M (metoclopramide); B (bromopride); and C (control, saline $0.9 \%$ ). Surgical procedures were performed identically in all animals, and consisted of a midline laparotomy followed by resection of a 1-cm segment of large bowel with end-to-end anastomosis. The abdominal wall was closed in two layers with running stitches. Abdominal wall samples were collected on the 3rd or 7th postoperative day for measurement of breaking (tensile) strength and histopathological assessment.

RESULTS: There were no statistically significant differences in tensile strength of the abdominal wall scar between groups M, B, and $\mathrm{C}$, nor between the three and seven days after surgery subgroups. On histopathological assessment, there were no statistically significant between-group differences in collagen deposition or number of fibroblasts at the wound site

CONCLUSION: Use of the prokinetic drugs metoclopramide or bromopride had no effect on abdominal wall healing in rats submitted to segmental colectomy and colonic anastomosis.

Key words: Abdominal Wall. Wound Healing. Gastrointestinal Motility. Metoclopramide. Rats.

\section{RESUMO}

OBJETIVO: Avaliar os efeitos do uso de drogas prócinéticas na cicatrização da parede abdominal de ratos submetidos à colectomia segmentar e anastomose no cólon esquerdo.

MÉTODOS: Foram utilizados 60 ratos, alocados aleatoriamente em três grupos para receberem as seguintes medicações no período pós-operatório: M (metoclopramida); B (bromoprida) e C (solução salina a $0,9 \%$ ). Os procedimentos cirúrgicos foram idênticos em todos os animais. Foi realizada laparotomia mediana, seguida de colectomia segmentar de 1-cm e anastomose colônica. O fechamento da parede abdominal foi feito em dois planos de sutura contínua. No $3^{\circ}$ ou no $7^{\circ}$ dia pós-operatório foram coletadas amostras da parede abdominal para medida da força de ruptura e avaliação histopatológica.

RESULTADOS: Não houve diferença significativa entre os grupos no que diz respeito à força de ruptura da parede abdominal, nem entre os subgrupos no $3^{\circ}$ e $7^{\circ}$ dia após a cirurgia. À análise histopatológica não houve alterações na deposição de colágeno ou na quantidade de fibroblastos no sítio da cicatriz.

CONCLUSÃO: O uso de drogas prócinéticas, metoclopramida ou de bromoprida, não interferiu na cicatrização da parede abdominal de ratos submetidos à colectomia segmentar e anastomose no cólon esquerdo.

Descritores: Parede Abdominal. Cicatrização. Motilidade Gastrointestinal. Metoclopramida. Ratos. 


\section{Introduction}

Abdominal wall dehiscence and incisional hernia are the most common complications of surgical procedures that require laparotomy for access to the peritoneal cavity ${ }^{1,2}$. The 10-year prevalence of incisional hernia may be as high as $20 \%$, and that of wound dehiscence, $0.2-11 \%$; both complications are associated with adverse economic impact and worse patient quality of life $\mathrm{e}^{3,4}$.

The predominant cause of these complications is acute failure of the sequential, multifactorial process that leads to adequate wound healing ${ }^{1,5}$. In the United States alone, approximately 6 million people are affected by nonhealing wounds, which lead to an annual health expenditure of US\$ 3 billion $^{6}$.

The healing process begins with hemostasis ${ }^{5,7}$. This is followed by the inflammatory response, during which macrophages and polymorphonuclear neutrophils migrate from the circulation to the wound site in response to increasing cytokine levels ${ }^{5,8}$. Later stages include proliferation of blood vessels and fibroblasts with formation of granulation tissue, collagen synthesis, connective tissue remodeling, and acquisition of tensile strength ${ }^{5,9}$.

A variety of factors that affect this sequence of biological processes, which normally culminates with the restoration of tissue integrity, may lead to poor healing. These risk factors include ischemia, infection, stress, diabetes, obesity, alcoholism, smoking, poor nutrition, and medication use $\mathrm{e}^{2,5,10}$.

Prokinetic agents are often used in the early postoperative period to aid gastric emptying and speed resolution of paralytic ileus, particularly after intestinal surgery ${ }^{11,12}$. The prokinetic class includes the substituted benzamides, such as metoclopramide and bromopride, which act as dopamine antagonists. These drugs have antiemetic and motility-stimulating effects ${ }^{13}$.

It is reasonable to assume that prokinetic agents may exert a systemic effect on the healing process due to their antagonist effect at dopamine receptors. Dopamine (and its receptors) plays a crucial role in healing, as it inhibits production of VEGF, the growth factor responsible for angiogenesis and cell proliferation ${ }^{9,14}$. Likewise, cathepsin D-cleaved prolactin fragments have an antiangiogenic effect ${ }^{15,16}$. It is known that use of prokinetic agents increases serum prolactin levels, and that angiogenesis plays a crucial role in the neovascularization of granulation tissue during the healing process.

In a rat model study of abdominal wall healing in septic conditions, Silva et al. ${ }^{17}$ found that metoclopramide increases the tensile strength of the wound scar three days after surgery and decreases surgical site inflammation maybe due to increased levels of prolactin, which acts as an analgesic and immunomodulator. A similar study, also under septic conditions, found that bromopride had no effect on abdominal wall healing ${ }^{18}$. The effects of prokinetic agents on wound healing of the abdominal wall under non-pathological conditions is not clear.

The aim of this study was to assess the effect of two prokinetic agents - metoclopramide and bromopride - on abdominal wall healing in rats after colectomy and colonic anastomosis.

\section{Methods}

This randomized, single-blind, placebo-controlled experimental study was carried out at the Experimental Surgery Lab of the University of Brasilia. Local Animal Research Ethics Committee approval was obtained prior to the study.

The sample comprised 60 healthy male Wistar rats (Rattus norvegicus). Animals were allowed one week to acclimatize and were fed on a standard diet and water ad lib. Rats were allocated into three groups of 20 animals each, which were then subdivided into two groups of 10 animals each depending on the planned date of euthanasia three or seven days after surgery (DAS). Groups were named according to the intervention administered daily throughout the postoperative period:

$\rightarrow$ Metoclopramide (M): subcutaneous injection of metoclopramide, $1 \mathrm{mg} / 100 \mathrm{mg}$;

$\rightarrow$ Bromopride (B): subcutaneous injection of bromopride, $1 \mathrm{mg} / 100 \mathrm{mg}$;

$\rightarrow$ Control (C): subcutaneous injection of saline, in volumes equal to those of metoclopramide and bromopride.

Rats were anesthetized with an intramuscular injection of xylazine $(10 \mathrm{mg} / \mathrm{kg})$ and ketamine $(75 \mathrm{mg} / \mathrm{kg})$. The anterior abdominal wall was shaved and disinfected with povidoneiodine. A 4-cm midline incision was made starting $1 \mathrm{~cm}$ cranial to the external genitalia. The left colon was exposed and a $1-\mathrm{cm}$ segment, located 2.5 to $3.5 \mathrm{~cm}$ from the peritoneal reflection, was resected. End-to-end anastomosis was performed with running sutures (6.0 polypropylene), followed by double-layer closure of the abdominal wall, also with running sutures (3.0 silk). Tramadol ( $0.01 \mathrm{mg} / \mathrm{kg}$ subcutaneously every 12 hours) was administered for postoperative analgesia.

Reoperation was performed three or seven days after surgery, depending on subgroup. Animals were anesthetized and prepared as for the first operation. Two samples of abdominal wall containing a segment of the surgical scar were resected: one 1-cm wide sample for measurement of tensile strength and one for histopathological analysis. Animals were euthanized with an 
overdose of thiopental.

Tensile strength was measured with a digital device (Versa Test, Mecmesin Versa Test, United Kingdom) coupled with an AGF digital dynamometer (Mecmesin Versa Test, United Kingdom). Strength was expressed in newtons $(\mathrm{N})$.

A trained pathologist, blind to group allocation, performed light microscopy analysis of samples after hematoxylin and eosin (H\&E) staining. The following indicators were assessed: collagen and fibroblast content, mononuclear inflammatory infiltrate, polymorphonuclear inflammatory infiltrate, vascular neoformation, and edema. Each of these indicators was graded as absent (0), slight/mild (1), moderate (2), marked (3), or intense (4). Abscess formation, foreign body reaction, and fibrin were noted as present (1) or absent (0).

Statistical analyses were performed in the $\operatorname{SPSS}^{\circledR} 18.0$ software package. The Kruskal-Wallis test was used for betweengroup comparison of tensile strength. Fisher's exact test was used to analyze histopathological data. The significance level was set at $\mathrm{p}<0.05$.

\section{Results}

There was one premature death in the postoperative period: an animal in group $M$ with euthanasia scheduled for the 7 th postoperative day. This death could not be attributed to complications associated with the surgical wound or abdominal cavity.

There were no statistically significant differences in tensile strength of the abdominal wall scar between groups $\mathrm{M}, \mathrm{B}$, and $\mathrm{C}$, nor between the three and seven DAS subgroups (Figures 1 and 2).

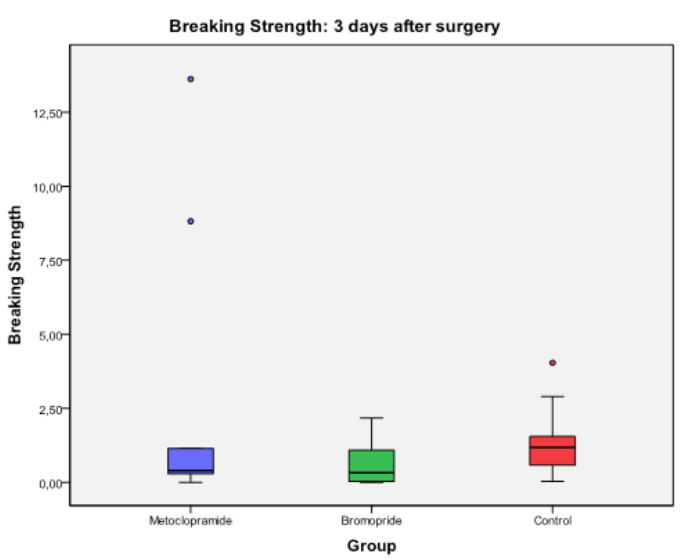

FIGURE 1 - Distribution of abdominal wall wound breaking strength (expressed in newtons) three days after surgery. Group $\mathrm{M}$ (metoclopramide) shown in blue, group B (bromopride) shown in green, and group $\mathrm{C}$ (control) shown in red. Solid circles above the box plot and printed in the same color represent outliers.

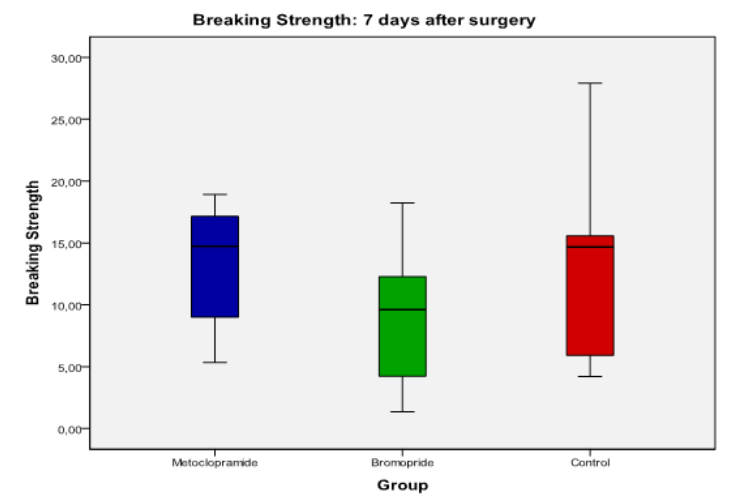

FIGURE 2 - Distribution of abdominal wall wound breaking strength (expressed in newtons) seven days after surgery. Group $\mathrm{M}$ (metoclopramide) shown in blue, group B (bromopride) shown in green, and group $\mathrm{C}$ (control) shown in red.

On histopathological assessment, there were no statistically significant between-group differences in collagen deposition or number of fibroblasts at the wound site (Tables 1 and 2).

TABLE 1 - Median (m), minimum (min) and maximum (max) of scores of histopathological analysis of abdominal wall scar samples, animals killed three days after surgery. Groups $\mathrm{M}$ (metoclopramide), B (bromopride) and C (control).

\begin{tabular}{ccccc}
\hline & $\begin{array}{c}\mathbf{M} \\
\mathbf{m} \\
(\mathbf{m a x} / \\
\mathbf{m i n})\end{array}$ & $\begin{array}{c}\mathbf{B} \\
\mathbf{m} \\
(\mathbf{m a x} / \\
\mathbf{m i n})\end{array}$ & $\begin{array}{c}\mathbf{C} \\
\mathbf{m} \\
(\mathbf{m a x} / \\
\mathbf{m i n})\end{array}$ & $\mathbf{p}$ \\
\hline Collagen & $0(0 / 0)$ & $0(1 / 0)$ & $0(1 / 0)$ & 1.000 \\
Fibroblast & $2(2 / 1)$ & $2(3 / 1)$ & $2(3 / 1)$ & 1.000 \\
Mononuclear & $2(3 / 1)$ & $2(3 / 1)$ & $2(3 / 0)$ & 1.000 \\
Polymorphonuclear & $2(2 / 1)$ & $2(2 / 1)$ & $2(2 / 1)$ & 0.270 \\
Edema & $2(3 / 1)$ & $2(3 / 2)$ & $2(3 / 1)$ & 0.520 \\
Neovascularization & $2(3 / 1)$ & $2(3 / 1)$ & $2(3 / 1)$ & 0.220 \\
\hline
\end{tabular}


TABLE 2 - Maximum, minimum, and median (m) scores of histopathological analysis of abdominal wall scar samples; animals killed seven days after surgery. Groups $\mathrm{M}$ (metoclopramide), B (bromopride) and C (control).

\begin{tabular}{|c|c|c|c|c|}
\hline & $\begin{array}{c}\mathbf{M} \\
\mathbf{m} \\
(\mathbf{m a x} / \\
\mathbf{m i n})\end{array}$ & 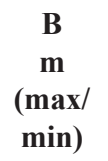 & $\begin{array}{c}\mathbf{C} \\
\mathbf{m} \\
(\mathbf{m a x} / \\
\mathbf{m i n})\end{array}$ & $\mathbf{p}$ \\
\hline Collagen & $1(1 / 0)$ & $1(1 / 0)$ & $1(1 / 0)$ & 0.659 \\
\hline Fibroblast & $3(3 / 0)$ & $3(3 / 1)$ & $3(3 / 1)$ & 0.594 \\
\hline Mononuclear & $3(3 / 0)$ & $3(3 / 1)$ & $2(2 / 1)$ & $0.002 *$ \\
\hline Polymorphonuclear & $3(3 / 0)$ & $3(3 / 0)$ & $3(3 / 1)$ & 0.408 \\
\hline Edema & $1(2 / 0)$ & $1(1 / 0)$ & $2(2 / 1)$ & $0.014 *$ \\
\hline Neovascularization & $3(3 / 0)$ & $3(3 / 0)$ & $3(3 / 1)$ & 0.823 \\
\hline
\end{tabular}

The only statistically significant differences between the three DAS subgroups were in presence of foreign body $(p=0.001)$ and fibrin $(p=0.019)$. As shown in Tables 2 and 4, there were fewer rats with foreign body reaction in animals given metoclopramide and less fibrin in those given bromopride.

Among animals killed seven DAS, there was increased mononuclear infiltration $(\mathrm{p}=0.002)$ in the bromopride group. Edema $(p=0.014)$ and foreign body reaction $(p=0.027)$ were less common in the $\mathrm{M}$ and $\mathrm{B}$ groups than in the control group (Tables 3 and 4).

TABLE 3 - Histopathological analysis of animals killed seven days after surgery, in groups M (metoclopramide), B (bromopride) and C (control).

\begin{tabular}{ccccc}
\hline & $\begin{array}{c}\text { M (n } \\
=\mathbf{1 0}), \\
\text { present/ } \\
\text { absent }\end{array}$ & $\begin{array}{c}\text { B (n } \\
=\mathbf{1 0}), \\
\text { present/ } \\
\text { absent }\end{array}$ & $\begin{array}{c}\mathbf{C}(\mathbf{n}) \\
\mathbf{1 0}) \\
\text { present/ } \\
\mathbf{a b s e n t}\end{array}$ & $\mathbf{p}$ \\
\hline Abscess & $7 / 3$ & $8 / 2$ & $8 / 2$ & 1.000 \\
Fibrin & $6 / 4$ & $1 / 9$ & $7 / 3$ & $0.019^{*}$ \\
Foreign body & $2 / 8$ & $9 / 1$ & $9 / 1$ & $0.001^{*}$ \\
\hline *Statistically significant difference & & &
\end{tabular}

*Statistically significant difference
TABLE 4 - Histopathological analysis of animals killed seven days after surgery, in groups $\mathrm{M}$ (metoclopramide), B (bromopride) and C (control).

\begin{tabular}{|c|c|c|c|c|}
\hline & $\begin{array}{c}\text { M (n } \\
=9), \\
\text { present/ } \\
\text { absent }\end{array}$ & $\begin{array}{c}\text { B }(\mathbf{n} \\
=10), \\
\text { present } / \\
\text { absent }\end{array}$ & $\begin{array}{c}C(\mathbf{n} \\
=10), \\
\text { present/ } \\
\text { absent }\end{array}$ & $\mathbf{p}$ \\
\hline Abscess & $5 / 4$ & $9 / 1$ & $8 / 2$ & 0.224 \\
\hline Fibrin & $1 / 8$ & $1 / 9$ & $3 / 7$ & 0.574 \\
\hline Foreign body & $5 / 4$ & $9 / 1$ & $10 / 0$ & $0.027 *$ \\
\hline
\end{tabular}

In light of the frequency and severity of the healing complications of abdominal wall closure, the present study sought to assess the influence of prokinetic agents on healing of the abdominal wall muscles and their aponeuroses.

This study assessed abdominal wall healing, but the underlying experimental surgery model consisted of a segmental colectomy followed by end-to-end colonic anastomosis. This procedure was based on the principle that experimentation should simulate a real-world human clinical practice scenario.

Laparotomy is predominantly a means of gaining access to the abdominal cavity so as to permit surgical intervention on intraabdominal organs; it is very rarely the primary surgical procedure. By adding colectomy and anastomosis and thus increasing the complexity of surgery, this model induces a metabolic response to surgical trauma that more closely mimics that of a true surgical procedure.

There were no statistically significant between-group differences in abdominal wall tensile strength. The scar tissue formed three and seven days after surgery was mature enough to withstand the physical stress that would have arisen in a real-world situation upon contraction of the abdominal muscles.

As collagen is deposited, resorbed, and remodeled in an organized fashion, the abdominal wall scar acquires tensile strength so it will be able to withstand the strain of abdominal muscle contraction ${ }^{4,5}$. Hence, study of tensile strength is highly relevant to assessment of healing, as it simulates the strains to which scar tissue will be subjected whenever the patient contracts his or her abdomen ${ }^{4,10}$.

In agreement with the results of tensile strength assessment, histopathological examination also failed to find any between-group differences in collagen deposition and number of 
fibroblasts at the wound site, whether three or seven days after surgery. The minor between-group differences in foreign body and presence of fibrin were not considered relevant, as they did not affect tensile strength or collagen or fibroblast deposition.

In the seven DAS euthanasia subgroup, animals who received metoclopramide or bromopride had less edema and foreign body reaction than controls. Foreign bodies may trigger mobilization, activation, and degranulation of mast cells, which induce increased capillary permeability, with consequent extravasation of fluid and protein into the interstitial compartment, leading to edema ${ }^{5,8}$. Therefore, edema may have been more marked in group $\mathrm{C}$ due to the presence of more animals with foreign bodies.

Bromopride and metoclopramide are antidopaminergic prokinetic agents used in conditions of abnormal gastrointestinal motility, such as functional dyspepsia, vomiting, and gastrointestinal stasis due to a variety of causes, including diabetic gastroparesis and postsurgical ileus ${ }^{11,19}$. The pharmacologic action of these drugs is mediated by enteric, neuronal, and muscular D2 receptor blockade ${ }^{11,19}$.

Antagonism of central D2 receptors produces both therapeutic and adverse effects, with the latter including dystonic extrapyramidal reactions and galactorrhea secondary to hyperprolactinemia ${ }^{19}$. The dose of prokinetic agents administered in this study was not high enough to induce any of these adverse effects. Therefore, it would be interesting for this study to be replicated in future, but with higher doses of bromopride and metoclopramide.

Dopamine acts as a potent suppressor of the expression of growth factors, which play a crucial role in the healing process ${ }^{10,18,19}$. Therefore, it would be reasonable to expect that dopamine would exert a negative impact on healing, and that blockade of dopamine action, as effected by bromopride and metoclopramide, would be beneficial.

However, Nishikawa et al. ${ }^{14}$ reported that exogenous administration of dopamine failed to affect gastric ulcer healing or VEGF and Flk-1 expression in rats; levels of both growth factors remained elevated at the wound site. Therefore, it is also reasonable to presume that administration of dopamine antagonists, such as bromopride and metoclopramide, would not alter the levels or effects of growth factors at the wound site and would thus have no influence on abdominal wall healing, as found in the present study.

\section{Conclusion}

Administration of metoclopramide or bromopride did not interfere with abdominal wall healing in rats.

\section{References}

1. Franz MG. The biology of hernias and the abdominal wall. Hernia. 2006;10:462-71.

2. Xing L, Culbertson EJ, Wen Y, Robson MC, Franz MG. Impaired laparotomy wound healing in obese rats. Obes Surg. 2011;21:193746.

3. Höer J, Lawong G, Klinge U, Schumpelick V. Factors influencing the development of incisional hernia. A retrospective study of 2,983 laparotomy patients over a period of 10 years. Chirurg. 2002;73:47480 .

4. Watanabe AL, Watanabe LM. Effects of tenoxicam on abdominal wall healing: experimental study in rats. Acta Cir Bras. 2005;20:1403.

5. Guo S, Dipietro LA. Factors affecting wound healing. J Dent Res. 2010;89:219-29.

6. Menke NB, Ward KR, Witten TM, Bonchev DG, Diegelmann RF. Impaired wound healing. Clin Dermatol. 2007;25:19-25.

7. Tognini JRF, Fagundes DJ, Novo NF, Juliano Y. Biomechanical and morphological study in rats' abdominal wall healing under meloxicam action. Acta Cir Bras. 2000;15:146-55.

8. Noli C, Miolo A. The mast cell in wound healing. Vet Dermatol. 2001;12:303-13.

9. Goldman R. Growth factors and chronic wound healing: past, present, and future. Adv Skin Wound Care. 2004;17:24-35.

10. Lopes JV, Freitas LA, Marques RD, Bocca AL, Sousa JB, Oliveira PG. Analysis of the tensile strength on the healing of the abdominal wall of rats treated with infliximab. Acta Cir Bras. 2008;23:441-6.

11. Verlinden M, Michiels G, Boghaert A, de Coster M, Dehertog P. Treatment of postoperative gastrointestinal atony. Br J Surg. 1987;74:614-7.

12. Jian R, Ducrot F, Piedeloup C, Mary JY, Najean Y, Bernier JJ. Measurement of gastric emptying in dyspeptic patients: effect of a new gastrokinetic agent (cisapride). Gut. 1985;26:352-8.

13. Longo WE, Vernava AM 3rd. Prokinetic agents for lower gastrointestinal motility disorders. Dis Colon Rectum. 1993;36:696708.

14. Nishikawa K, Amagase K, Takeuchi K. Effect of dopamine on the healing of acetic acid-induced gastric ulcers in rats. Inflammopharmacology. 2007;15:209-13.

15. Lee J, Majumder S, Chatterjee S, Muralidhar K. Inhibitory activity of the peptides derived from buffalo prolactin on angiogenesis. J Biosci. 2011;36:341-54

16. Piwnica D, Touraine P, Struman I, Tabruyn S, Bolbach G, Clapp C, Martial JA, Kelly PA, Goffin V. Cathepsin D processes human prolactin into multiple $16 \mathrm{~K}$-like N-terminal fragments: study of their antiangiogenic properties and physiological relevance. Mol Endocrinol. 2004;18:2522-42.

17. da Silva NG, Brandão AM, de Oliveira MV, Morais PH, Silva SM, Carneiro FP, Sousa JB. Influence of metoclopramide on abdominal wall healing in rats subjected to colonic anastomosis in the presence of peritoneal sepsis induced. Acta Cir Bras. 2011;26:92-9.

18. Oliveira MV, Brandao AM, Morais PH, Silva NG, Silva SM, Carneiro FP, Sousa JB. Effects of bromopride on abdominal wall healing with induced peritoneal sepsis after segmental colectomy and colonic anastomosis in rats. Acta Cir Bras. 2011;26:433-7.

19. Tonini M, Cipollina L, Poluzzi E, Crema F, Corazza GR, De Ponti F. Review article: clinical implications of enteric and central D2 receptor blockade by antidopaminergic gastrointestinal prokinetics. Aliment Pharmacol Ther. 2004;19:379-90. 
Correspondence:

João Batista de Sousa

Campus Universitário Darcy Ribeiro

Faculdade de Medicina

Laboratório de Cirurgia Experimental

70910-900 Brasília - DF Brasil

Tel.: (55 61)31071929

sousajb@unb.br

Received: February 23, 2012

Review: April 20, 2012

Accepted: May 18, 2012

Conflict of interest: none

Financial source: none

${ }^{1}$ Research performed at Experimental Laboratory of Surgery, School of Medicine, University of Brasilia (UnB), Brazil. 